\title{
Effect of Diet Supplemented with Dennettia Tripetala Fruits on Serum Antioxidants and Biochemical Parameters of Albino Rats
}

\author{
Adebiyi H. Yetunde ${ }^{{ }^{1}}$, Dauda Muhammed ${ }^{2}$, Babatunde O. Richard ${ }^{3}$, Odey O. Bernard $^{4}$, \\ Aderemi C. Omolaiye $^{1}$, Suleiman I. Onoruoiza ${ }^{1}$ \\ ${ }^{1}$ Department of Biochemistry Federal University of Technology Minna, Nigeria. \\ ${ }^{2}$ Southern Guinea savanna Research Stattion, Mokwa, Nigeria \\ ${ }^{3}$ Agricultural Extension and Management, Federal College of Forestry Ibadan, Nigeria \\ ${ }^{4}$ Trial Afforestation Research Station, Forestry Research Institute of Nigeria, Afaka-Kaduna State Nigeria
}

\begin{abstract}
This study was carried out to determine the effect of dietary supplementation of Dennettia tripetala on some biochemical parameters of rats. Twenty-five rats were used and were divided in to five groups of 5 rats. Group 1 served as control while group 2-5 were fed dietary inclusion of Dennettia tripetala fruits for 28 days. After the feeding trials, the rats were sacrificed and blood was collected for biochemical analyses. The serum concentration triglyceride and glucose were significantly lowered $(p<0.05)$ while total protein, catalase and high-density lipoprotein were significantly higher $(p<0.05)$ in rats fed with the formulated diet. There was no significant difference $(p<0.05)$ in the serum level of superoxide dismutase, albumin, cholesterol and low-density lipoprotein of rats fed with the formulated diet. In conclusion, the study has shown that dietary inclusion of Dennettia tripetala fruits has hypoglycaemic, antioxidant and hypolipidemic effect. Therefore, it may help in the prevention of coronary heart disease, diabetes mellitus and cancer.
\end{abstract}

Keywords: Dennettia tripetala, Diet, Antioxidants, Biochemical parameters.

\section{Introduction}

In Nigeria, many indigenous plants are used as spices, food or medicine. A great number of these plants are traditionally recognized for their medicinal properties. Dennettia tripetala (pepper fruit) is one of these plants. Dennettia tripetala (Annonaceae) is widely consumed by Southern Nigerians and it is found in the tropical rainforest region of Nigeria and sometimes in Savana areas [1]. It is locally called "Nkarika" (in Efiks of Calabar), "Nmimi" (in Igbo), and "Igbere" (in Yoruba). The mature fruits have a spicy taste and constitute the main edible portions [2]. The fruits are green when developing, but start to turn red

\footnotetext{
* Corresponding author: Adebiyi H. Yetunde, hanahrinkoff.1631@gmail.com

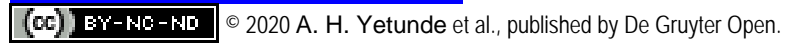
This work was licensed under the Creative Commons Attribution-NonCommercialNoDerivs 3.0 License
}

with ripening [3]. The moisture content also increases with ripening. The fruits have a very strong characteristic smell. The leaves are 3-6 inches long and 1.5-2.5 inches broad. They are elliptic in shape. The fruits are made up of the seeds and a spicy flesh. The fruit and seeds are edible and are consumed because of the spicy nature. The wood is used as fuel. The plant usually produces fruit between the months of March and May. For this reason, local traders preserve the seeds of pepper fruit by drying it under the sun in order to ensure continuous availability until the next harvest [4].

The leaves and roots are utilized, in addition to the fruits, for medicinal purposes, especially in the southern part of Nigeria [5]. Dennettia tripetala (pepper fruit) is used traditionally to treat cough, fever, toothache, diabetes, and nausea. The fruits are rich source of protein, carbohydrates, crude fiber, antioxidant, vitamins $\mathrm{A}, \mathrm{C}$ and $\mathrm{E}$. The plant 
has phytochemicals that have been shown to possess antimicrobial, insecticidal, analgesic and anti-inflammatory properties. The plant has also been reported to elicit chemotherapeutic, anti hyperglycemic, and antioxidant properties [6]. As masticators and stimulants, $D$. tripetala fruits/seeds produce unique peppery effect when chewed [7]. Dennettia tripetala seeds are applied to diets of pregnant and postpartum women to aid uterine contraction $[4,8]$.

\section{Material and Methods}

Plant material

D. tripetala fruits were purchased from orange Market, Abuja on the $5^{\text {th }}$ of June, 2017. The fruits were washed and dried. The dried fruits were grounded into powder form using electric blender.
Experimental Design

Twenty-five Albino Rats of approximately 21-28 days old were used in the study. The rats were obtained from the Animal house, University of Jos, Plateau State.

They were made to acclimatize for one week and then divided into five groups having five rats per group. They were allotted to five dietary treatment containing graded levels of, 0, 5, 10, 15 and 20\% of pepper fruits. The rats were caged, fed daily with formulated diets and were allowed free access to water ad libitum throughout the study period. Their feed intake and growth was monitored carefully for the period of 28 days of the experiment.

\section{Experimental diets composition (grams)}

Table 1.

\begin{tabular}{lccccc}
\hline Ingredients (\%) & G1(0\%DT) & G2(5\% DT) & G3(10\%DT) & G4(15\% SE) & G5(20\%DT) \\
\hline Maize & 400 & 350 & 300 & 250 & 200 \\
Rice bran & 300 & 300 & 300 & 300 & 300 \\
D. tripetala fruit & 00 & 50 & 100 & 150 & 200 \\
Groundnut cake & 200 & 200 & 200 & 200 & 200 \\
Groundnut oil & 40 & 40 & 40 & 40 & 40 \\
Fish meal & 20 & 20 & 20 & 20 & 20 \\
Bone meal & 25 & 25 & 25 & 25 & 25 \\
Minerals & 2 & 2 & 2 & 2 & 2 \\
Methionine & 4 & 4 & 4 & 4 & 4 \\
Lysine & 4 & 4 & 4 & 4 & 4 \\
Vitamins & 2.5 & 2.5 & 2.5 & 2.5 & 2.5 \\
Salt & 2.5 & 2.5 & 2.5 & 2.5 & 2.5 \\
\hline
\end{tabular}

Total $=1000 \mathrm{~g} \quad$ G1-5 $=$ GROUP 1-5 DT = Dennettia tripetala

\section{Blood Sample Collection and Analysis}

The rats were sacrificed after 28 days of feeding and blood samples were collected from four rats per group for biochemical studies. The rats were anaesthetized using chloroform and sacrificed. The blood samples were collected into labeled ethylene diamine tetra acetic acid (EDTA) bottle studies. The biochemical parameters studied on each blood sample were lipid profile (total cholesterol, triglycerides, High Density Lipoprotein and Low Density Lipoprotein), albumin, total protein, glucose, superoxide dismutase (SOD) and catalase. The biochemical parameters were determined using commercial kits [12, 13].

Statistical Analysis

Values were analyzed by statistical package for social science (SPSS) version 16 and presented as means \pm standard error of the mean. Comparisons between different groups were done using one way analysis of variance (ANOVA) and Duncan's Multiple Range Test (DMRT). The level of significance was at set $P<0.05$.

\section{Results}

Effect of Diets Supplemented with D. tripetala Fruit on Lipid Profile of Rats

Figure 1 shows the effect of diets supplemented with $D$. tripetala fruit on lipid profile of rats. There was no significant difference $(P<0.05)$ in the serum level of cholesterol and low-density lipoprotein of rats fed with $D$. tripetala fruit. However, there was a significant difference $(P<0.05)$ in the level of triglycerides and highdensity lipoprotein in the serum of rats fed with dietary inclusions of $D$. tripetala fruit.

Effect of Diets Supplemented with D. tripetala Fruit on Serum Concentration of Protein and Albumin of Rats 
Figure 2 shows the effect of diets supplemented with $D$. tripetala fruit on serum concentration of total protein and albumin of rats. The serum protein concentration of rats fed with dietary inclusions of $D$. tripetala fruit was significantly higher $(p<0.05)$ than the control. There was no significant difference in serum albumin level of rats fed with dietary inclusions of $D$. tripetala fruit compared to the control.

Effect of Diets Supplemented with D. tripetala Fruit on Serum Glucose Concentration of Rats

Figure 3 shows the effect of diets supplemented with $D$. tripetala fruit on serum glucose concentration of rats. It was observed that the serum glucose concentration was significantly lowered in rats fed with dietary inclusions of $D$. tripetala fruit compared to the control.

Effect of Diets Supplemented with D. tripetala Fruit on Serum Superoxide Dismutase and Catalase Activity of Rats

The result (Figure 4) shows that there was a significant $(p<0.05)$ difference between serum SOD and catalase activities of rats fed with diets supplemented with $D$. tripetala fruit compared to the control. The serum SOD and catalase activity of rats fed with diet supplemented with $D$. tripetala fruit was significantly higher $(p<0.05)$ than the control.
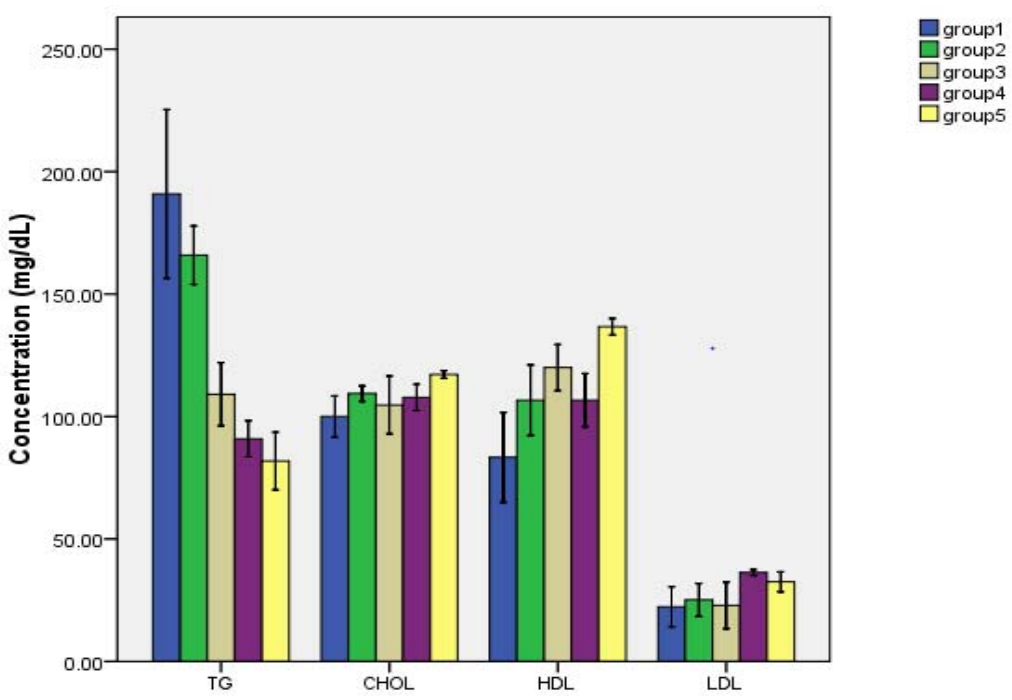

Figure 1. Effects of Diets Supplemented with D. tripetala Fruit on Lipid Profile of Rats. Values are mean of four (4) determinations. Bars with different superscripts are significantly different at $p<0.05$. Keys: TG-

Triglyceride, CHOL - Cholesterol, HDL - High Density Lipoprotein, LDL - Low Density Lipoprotein
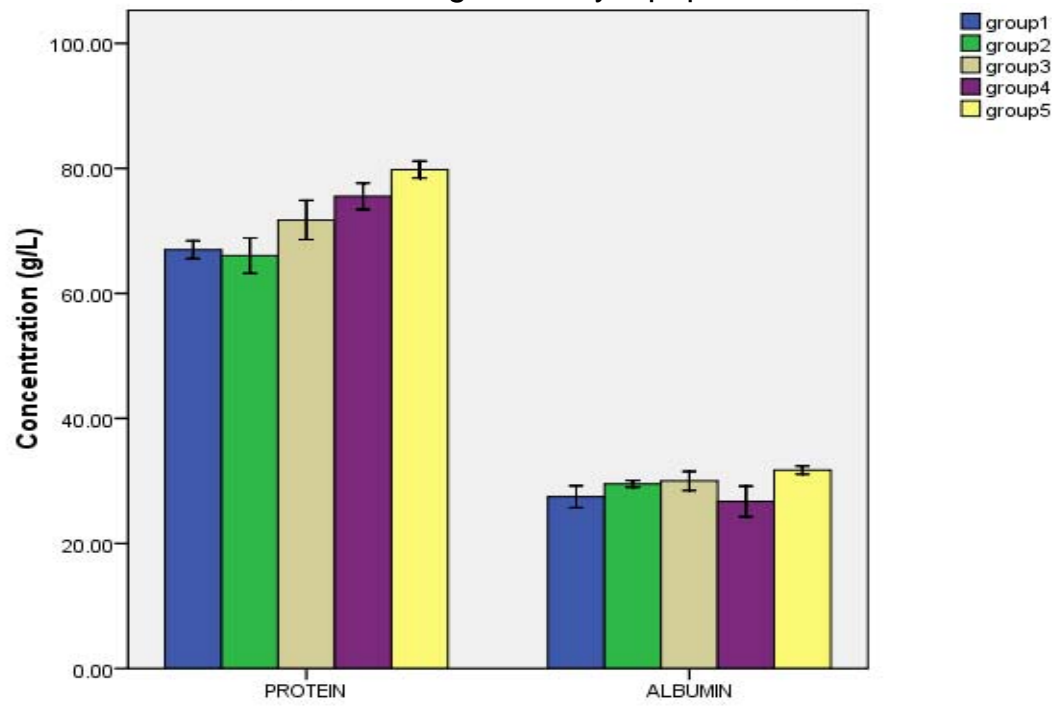

Figure 2. Effects of Diets Supplemented with D. tripetala Fruit on serum Total Protein and Albumin of Rats. Values are mean of four (4) determinations. Bars with different superscripts are significantly different at $p<0.05$ 

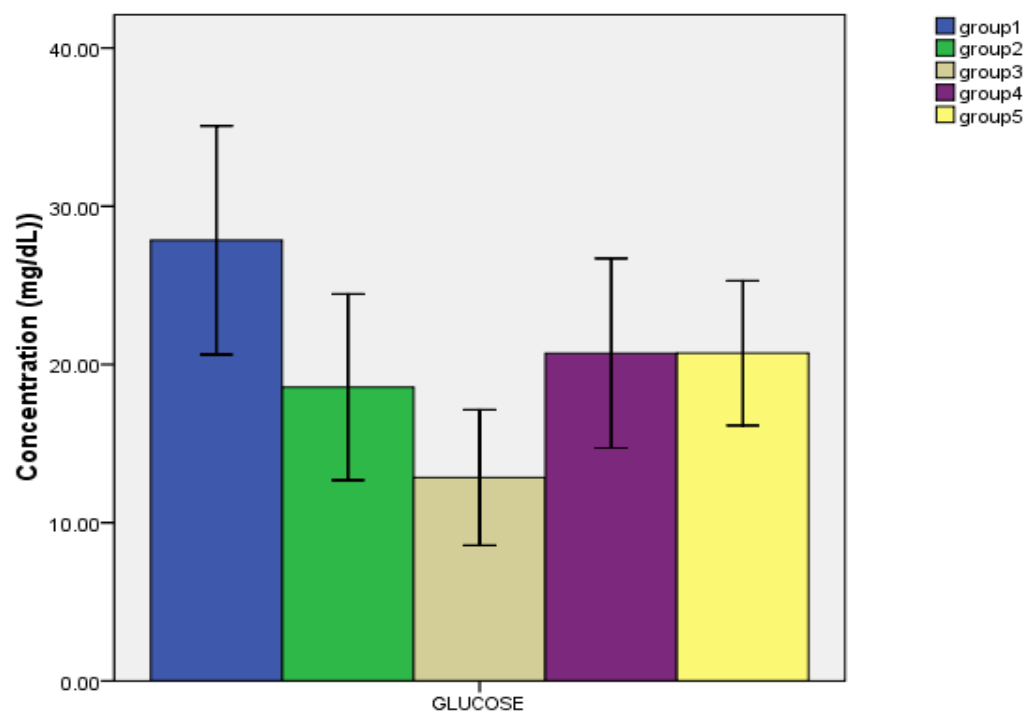

Figure 3. Effects of Diets Supplemented with $D$. tripetala Fruit on Serum Glucose of Rats. Values are mean of four (4) determinations. Bars with different superscripts are significantly different at $p<0.05$.

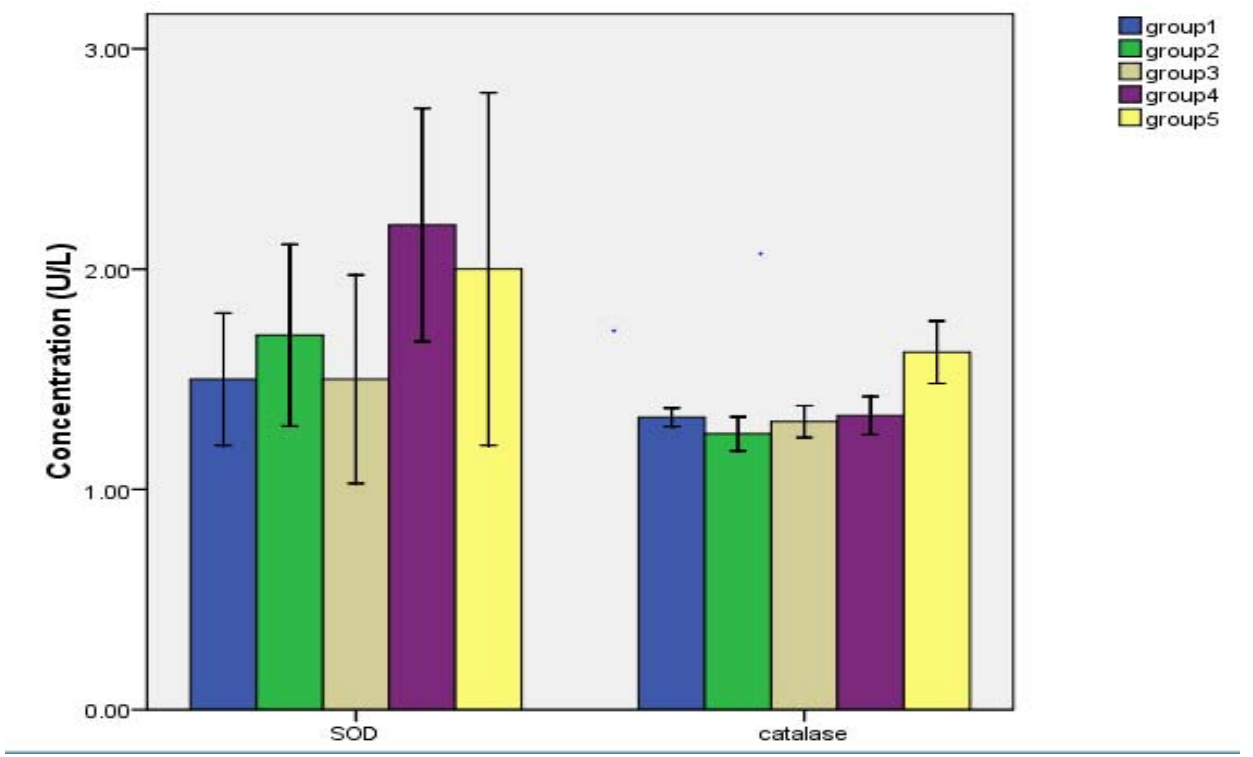

Figure 4. Effects of Diets Supplemented with $D$. tripetala Fruit on Serum SOD and Catalase Activity. Values are mean of four (4) determinations. Bars with different superscripts are significantly different at $p<0.05$.

\section{Discussions}

The measurement of serum biochemical parameters are commonly used as diagnostic tools in monitoring individual health [9] and in assessing the ability of body to respond to nutritional changes [10]. These parameters allow for the detection of the pathophysiological changes attributable to nutrition. The result of the present study (figure 1) showed that the serum TG level was significantly lowered in rats fed with diets supplemented with $D$. tripetala fruit compared to the control. There was no significant difference in the serum cholesterol and Low Density Lipoprotein cholesterol levels in rats fed with diets supplemented with $D$. tripetala compared to the control. The result also revealed that dietary inclusions of $D$. tripetala fruit significantly increase the serum HDL level as compared to the control group. The hypolipidemic effect observed in rats fed with dietary inclusions of $D$. tripetala fruit could be attributed to the high fibre content of the fruit. Fibre decreases lipid absorption by adsorbing fatty acids, cholesterol and bile acids in the digestive tract, this prevent them from forming micelles and therefore, they cannot be absorbed in their bound form. The fibrebound lipids are transported to the large intestine where they are excreted or degraded by colonic 
bacteria [11]. The observed increase in the serum HDL-C level and decrease in serum TG level suggest a reduced risk in the development of atherosclerosis.

Serum concentrations of protein and albumin are used as marker for the synthetic and excretory functioning of the liver and kidney [12]. The observed increase in the total serum protein level (Figure 2) of rats fed with diets supplemented with $D$. tripetala fruit is an indication that the fruit is a good source of dietary protein and could be due to the high protein content of the fruit.

The serum glucose concentration (Figure 3 ) of rats fed with dietary inclusions of $D$. tripetala fruit was significantly lowered $(p<0.05)$ than the control. The observed decrease in serum glucose concentration indicates that the fruit has hypoglycaemic effect. The glucose lowering effect of $D$. tripetala fruit could be due to the presence of some bioactive substance such as flavonoids, saponins and alkaloids [13]. The hypoglycaemic effect may also be as a result of high fibre content recorded for $D$. tripetala fruit in this study which help to reduce glucose absorption and delay stomach emptying. The hypoglycaemic effect of this fruit, therefore, implies that it may be used in the prevention of diabetes mellitus.

Antioxidants play important role in human health. The coordinate activities of antioxidant systems are essential for the detoxication of free radicals. Superoxide dismutase (SOD) elicits its antioxidant effect by converting highly reactive superoxide radicals to hydrogen peroxide $\left(\mathrm{H}_{2} \mathrm{O}_{2}\right)$ which is in turn converted to water $\left(\mathrm{H}_{2} \mathrm{O}\right)$ and oxygen $\left(\mathrm{O}_{2}\right)$ by catalase, therefore the protecting body tissues against free radicals [14]. The observed increase in the serum SOD and catalase activity could be due to the presence of some phytochemicals (phenols, flavonoids, tannins etc.), vitamin $A$ and vitamin $C$ in $D$. tripetala fruits $[15,16]$. Tannins have been shown to aid 'tarring' of the outermost layer of the mucose, thereby increasing the resistance of the membrane to chemical and mechanical stress or reduces it permeability to ions. The observed increase in the antioxidant enzymes assayed for suggest that $D$. tripetala fruit has antioxidant effect and may be essential in the prevention of atherosclerosis, coronary heart disease, diabetes mellitus and other oxidative stress-related disease.

\section{Conclusions}

The results of this study showed that diet supplemented with $D$. tripetala fruit has beneficiary effect on serum HDL-C, total protein, albumin, glucose and superoxide dismutase level. $D$. tripetala fruit at $15 \%$ inclusion rate may therefore be a good source of dietary nutrients that would contribute greatly to the nutritional requirement for normal growth and play important role in the prevention of various diseases such as coronary heart disease, diabetes mellitus and cancer.

\section{Acknowledgement}

I sincerely acknowledge and appreciate Dr. Oibiokpa Florence Inje for painstakingly and indefatigably reading through the manuscript, her meaningful assistance, instructions, contributions, guidance and kind gesture in making the research work a success. May God bless her soul!

\section{References}

1. Okwu, D. E. \& Morah, F. N. I. (2005). Isolation and Characterization of Phenanthrenic Alkaloid Uvariopsine from Dennettia tripetala Fruits. Journal of medicinal and aromatic plant science, 27, $496-498$.

2. Achinewhu, S. C., Ogbonna, C. C. \& Hart, A. D. (1995). Chemical Composition of Indigenous Wild Herbs, Spices, Fruits, Nuts and Leafy Vegetables used as Food. Plant Foods for Human Nutrition, 48(4), 341-348.

3. Ejechi, B.O. \& Akpomedaye, D. (2005). Activity of Essential Oil and Phenolic Extract of Pepper Fruits, DennettiatripetalaG. Baker Against Some Food-born Microorganisms.African Journal of Biotechnology, 3, 258-261.

4. Okwu, D. E. \& Morah, F. N. I. (2004). Mineral and Nutritive Value of DennettiatripetalaFruits. Fruits, 59, 437-442.

5. Iwu, M. (1989). Food for medicine, in Dietary Plants And Masticastors as Sources of Biologically Active Substances. University of Ife Press, Ife, Nigeria, pp. 303-310.

6. Bright, E., Mfem, C., Ugumanim, A. \& Ukpong, M. (2017). The Effect of Ethanol Extract of Dennettia tripetala (Pepper fruit) on Gastric Acid Secretion in Wistar Rats. Journal of Medical and Health Sciences, 6(3), 21-26.

7. Ikpi, D. E. \& Nku, O. (2008). Effect of Ethanolic Extract of Dennettia tripetala Fruit on Haematological Parameters in Albino Wistar Rats. Nigerian Journal of Physiological Sciences, 23, 13-17.

8. Achinewhu, S. G., Ogbonna, C. \& Hard, A. D. (1995). Chemical Composition of Indigenous Wild Herbs, Spices, Fruits, Nuts and Leafy Vegetables used as Food. Plants Food for Human Nutrition, 48, 341-348.

9. Dike, M.C. (2010). Proximate, Phytochemical and Nutrient Compositions of Some Fruits, Seeds and Leaves of Some Plant Species at Umudike, Nigeria. Journal of Agricultural and Biological Science, 5(1), 7-16. 10. Chipurara, B. (2010). Nutritional Content, Phenolic Compounds Composition and Antioxidant Activities of Selected Indigenous Vegetables of Zimbabwe. A Thesis Submitted to the Institute of Food, Nutrition and Family Sciences, Faculty of Science, University of Zimbabwe. pp 25-31.

11. Udeme, J.O., Kpobari, W.N., Joyce, O.A. \& Augustine, A.U. (2013). Proximate, Phytochemical and Mineral Composition of Some Edible Fruits Grown in Oil Producing Community of River State, Nigeria. IOSR 
Journal of Environmental Science, Toxicology and Food Technology, 5(2), 38-46.

12. Pugalenthi, M., Vadivel, V., Gurumoorthi, P. \& Janardhanan, K. (2004). Comparative Nutritional Evaluation of Little Known Legumes, Tamarindus indica, Erythrina indica and Sesbania bispinosa.Tropical and Subtropical Agroecosystem, 4, 107-123.

13. Egharevba, H. O. \& Idah, E. A. (2015). Major Compounds from the Essential Oil of the Fruit and Comparative Phytochemical Studies of the Fruits and Leaves of Dennettia tripetala Barker F. Found in North Central Nigeria. International Journal of Pharmacognosy and Phytochemical Research, 7(6), 1262-1266.
14. Perkins-Veazie, P.M., Collins, J.K. \& Robert, W. (2005). Screening Carotenoid Content in Seeded and Seedless Watermelon Fruit. Journal of Horticultural Science, 39, 830.

15. Amusa, N.A., Ashaye, O.E. \& Oladapo, M.O. (2003). Biodeterioration of Proximate Composition of African Star Apple in Storage and Effects on its Food Value. African Journal of Biotechnology, 2(3), 56-59.

16. Olesen, M. \& Gudman, H.E. (2000). Efficacy, Safety and Tolerability of Fructooligosaccharides in the Treatment of Irritable Bowel Syndrome. American Journal of Clinical Nutrition, 72,1570-1575. 